\title{
PERCIKAN PEMIKIRAN PENDIDIKAN HUMANIS RELIGIUS
}

\author{
Oleh : \\ Rukiyati \\ FSP FIP UNY \\ Email: rukiyati@uny.ac.id
}

\begin{abstract}
Abstrak : Terminologi pendidikan humanis religius diperkenalkan akhir-akhir ini sebagai konsep pendidikan yang menarik dibincangkan lebih lanjut, setidaknya karena dipandang sesuai dengan dasar falsafah pendidikan di Indonesia: Pancasila. Walaupun demikian, secara konseptual belum banyak ahli yang membahasnya. Penjernihan konsep pendidikan humanis religius perlu dilakukan sebagai upaya merumuskan teori pendidikan yang khas Indonesia. Merujuk pada tujuan pendidikan nasional, dapat diketahui bahwa pendidikan di Indonesia sedikit banyak dilandasi oleh konsep pendidikan humanis religius. Pemaparan lebih lanjut merupakan percikan pemikiran penulis dengan metode analisis-sintesis mencoba menarik makna yang terkandung di dalam konsep pendidikan humanis religius, dan landasan ontologis yang mendasarinya. Di samping itu, juga dilakukan refleksi atas fenomena pendidikan yang terjadi di Yogyakarta dilihat dari perspektif pendidikan humanis religius.
\end{abstract}

Kata kunci: Refleksi Pemikiran, Pendidikan, Humanis-Religius.

\section{Pendahuluan}

Pendidikan humanis religius menjadi wacana yang terus dikembangkan akhirakhir ini dan wacana ini perlu untuk dibahas dari berbagai aspek. Pada tahap awal hendaknya perlu kajian filosofis mengenai makna yang terkandung di dalamnya, landasan ontologis, epistemologis dan aksiologisnya. Semua itu diperlukan agar diperoleh konsep yang kokoh dan dapat dipertanggungjawabkan secara ilmiahfilsafati.

Dengan menggunakan metode analisis makna yang terkandung di dalam suatu kata atau pernyataan akan diperoleh kejelasan konsep mengenai pendidikan humanis religius. Ada tiga kata yang perlu dianalisis, yaitu pendidikan, humanis, religius. Dalam kajian filsafati, metode analisis adalah upaya mengurai atau memerinci suatu pengertian atau pernyataan sehingga jelas makna yang terkandung di dalamnya. Maksud pokok analisis ialah melakukan pemeriksaan secara konsepsional atas makna yang terkandung oleh istilah-istilah yang dipergunakan dalam pernyataan- 
pernyataan yang dibuat (Katsoff, 1986:23). Dalam hal ini, istilah yang akan dianalisis adalah pendidikan humanis religius. Perlu diketahui bahwa uraian terhadap makna tidak identik dengan kebenaran dalam kenyataan. Selain itu, digunakan pula metode hermeneutik atau interpretasi dalam upaya memahami makna pendidikan humanis religius dari sisi landasan filsafati, yaitu dari sisi landasan ontologisnya.

\section{Pengertian Pendidikan Humanis Religius}

Driyarkara (1989: 9) sebagai salah seorang pendidik humanis di Indonesia menyatakan bahwa pendidikan adalah usaha sadar untuk memanusiakan manusia muda. Pengertian Driyarkara tersebut menyiratkan pendidikan itu sebagai suatu kegiatan yang human. Manusia lebih dipandang sebagai subjek bukan objek semata. Dikatakan sebagai subjek, karena manusia sebagai peserta didik harus menentukan arahnya sendiri dalam proses pendidikan menuju pada kedewasaan.

Konsep "humanis" memiliki beberapa arti yang berkait erat dengan

"humanisme". Dalam Kamus Besar Bahasa Indonesia (kbbi.web.id) tersua pengertian humanis dan humanisme sebagai berikut:

1. Orang yang mendambakan dan memperjuangkan terwujudnya pergaulan hidup yang lebih baik, berdasarkan asas perikemanusiaan; pengabdi kepentingan sesama umat manusia;

2. Penganut paham yang menganggap manusia sebagai objek terpenting;

3. Penganut humanisme.

4. Humanisme diartikan sebagai berikut:

a. Aliran yang bertujuan menghidupkan rasa perikemanusiaan dan mencitacitakan pergaulan hidup yanag lebih baik;

b. Paham yang menganggap manusia sebagai objek studi terpenting;

c. Aliran zaman Renaissance yg menjadikan sastra klasik (dl bahasa Latin dan Yunani) sebagai dasar seluruh peradaban manusia;

d. Kemanusiaan.

Walaupun demikian, baik pendapat Driyarkara tentang humanisasi sebagai proses pendidikan maupun pengertian humanis dalam KBBI belum secara jelas mengaitkan dengan aspek keilahian sebagaimana tersirat dalam konsep pendidikan humanis- 
religius. Maka, perlu dikaji lagi upaya pendalaman makna religius agar menjadi takteragukan lagi maknanya. Pengertian religius di dalam KBBI diartikan sebagai bersifat religi; bersifat keagamaan; yang bersangkut-paut dengan religi.

Budi Hardiman (2007: 9) mengatakan bahwa kaum humanis di Italia pada zaman Renaissance merupakan orang terpandang dalam masyarakat. Mereka menjadi guru atau orang yang mempelajari kebudayaan, seperti gramatika, retorika, sejarah, seni puisi, dan filsafat moral. Oleh karena ilmu-ilmu tersebut memiliki kedudukan penting di zaman Renaissance, kaum humanis juga menjadi orang-orang yang terpandang dalam masyarakatnya. Mereka bahkan dianggap lebih tinggi dari seniman dan ahli hukum. Humanisme berupaya membuat sintesis antara iman kristiani, dan ilmu pengetahuan, kebudayaan antik dan tradisi Kristen. Tujuannya tidak hanya untuk memajukan seni, peradaban dan penghargaan atas martabat manusia, melainkan juga toleransi di antara agama-agama yang ada. Gerakan humanisme selanjutnya menyebar ke luar Italia. Jadi, dilihat dari perspektif historis dapat disimpulkan bahwa orang yang humanis sekaligus adalah orang yang religius; humanis religius menjadi satu kesatuan.

Sodiq A. Kuntoro mengemukakan pengertian pendidikan humanis religius yang lebih jelas. Dikatakannya bahwa istilah pendidikan humanis religius mengandung dua konsep pendidikan yang ingin diintegrasikan, yaitu pendidikan humanis dan pendidikan religius. Pendidikan humanis yang menekankan aspek kemerdekaan individu diintegrasikan dengan pendidikan religius agar dapat membangun kehidupan individual-sosial yang memiliki kemerdekaan, tetapi dengan tidak meninggalkan nilai-nilai keagamaan (Sodiq A. Kuntoro, 2013:5).

Memanusiakan manusia mengandung makna bahwa potensi dan bakat yang ada dalam diri hendak diaktualisasikan sehingga menjadi kenyataan. Wujudnya dapat berupa pengetahuan, keahlian, sikap dan moral yang baik sehingga manusia yang dididik tersebut menjadi manusia yang telah mencapai realisasi diri yang optimal. Potensi-potensi diri berkembang optimal karena ada upaya-upaya sadar untuk mengembangkannya sejak dalam kandungan sampai pada tahap perhentian perkembangan. Maka, tujuan pendidikan menjadi salah satu pembahasan yang fundamental dalam pendidikan. Terkait dengan konsep pendidikan humanis religius, tujuan pendidikan di Indonesia sebenarnya juga telah memiliki konsep yang bersifat 
humanis religius. Pasal 3 Undang-Undang Sistem Pendidikan Nasional menyatakan bahwa pendidikan bertujuan untuk mengembangkan potensi peserta didik agar menjadi manusia yang beriman dan bertakwa kepada Tuhan YME, berakhlak mulia, sehat, berilmu, cakap, kreatif, mandiri, dan menjadi warga negara yang demokratis serta bertanggung jawab.

Dapat disimpulkan bahwa pendidikan di Indonesia secara konseptual telah bersifat humanis religius. Bukan hanya dimensi horizontal tetapi justru yang pertama-tama adalah tujuan yang berdimensi vertikal.

Jadi, pendidikan humanis religius mengandung makna bahwa pendidikan sebagai usaha sadar berasaskan kemanusiaan untuk mewujudkan kehidupan peserta didik yang lebih baik, lebih bermartabat secara menyeluruh, baik dari aspek hubungan sesama manusia (dimensi horizontal) maupun hubungan dengan Yang Ilahi (dimensi vertikal).

Dari pengertian singkat tersebut dapat dibuat suatu konseptualisasi pendidikan humanis religius dari sisi landasan ontologis-filsafati sehingga diharapkan akan memperkokoh konsep pendidikan humanis religius.

\section{Landasan Ontologis Pendidikan Humanis Religius}

Yang menjadi dasar ontologis pendidikan adalah manusia, yaitu subjek yang sadar dirinya, perlu dididik dan dapat pula mendidik. Manusia adalah subjek sekaligus objek dalam pendidikan. Manusia adalah bagian dari alam semesta (imanen), tetapi mempunyai eksistensi sendiri yang dalam beberapa hal dapat mengatasi alam itu sendiri (transenden). Alam semesta adalah sesuatu yang baru dan fana. Sebagai sesuatu yang baru dan fana, alam tidak mungkin ada dengan sendirinya, melainkan diadakan oleh Sang Pencipta (Tuhan). Manusia diciptakan di dalam alam, tetapi dapat pula mengatasi alam dengan kekuatan rasionalnya. Tuhan, alam dan manusia adalah tiga substansi yang tidak terpisahkan di dalam relasi kemanusiaan dan religiusitas manusia.

Pengembangan konsep pendidikan humanis religius harus bertitik tolak dari dasar ontologis tiga substansi tersebut: Tuhan, manusia, alam. Tuhan dan alam tidak memerlukan pendidikan, tetapi manusia memerlukannya. Substansi sebagai manusia 
akan hilang apabila manusia tidak memperoleh pendidikan. Itulah sebabnya manusia dikatakan sebagai homo educandum: makhluk yang harus dididik dan sekaligus dapat mendidik. Timbul pertanyaan: bagaimana penjabaran konsep manusia yang menjadi dasar pengembangan pendidikan humanis religius tersebut?

Jika ditilik dari berbagai sumber, konsep kemanusiaan tidak dapat dilepaskan dari hakikat manusia itu sendiri. Pembahasan kemanusiaan yang utuh dalam dimensi horizontal dan dimensi vertikalnya telah dikemukakan oleh pemikir Indonesia: Notonagoro.

Notonagoro (1987: 15) menyatakan bahwa manusia adalah makhluk monopluralis. Manusia itu dalam keutuhannya dapat dilihat dari tiga aspek/dimensi: susunan kodrat, sifat kodrat, dan kedudukan kodrat. Susunan kodrat manusia itu terdiri dari dua unsur: raga/badan dan jiwa (cipta, rasa, karsa) yang keduanya tidak terpisahkan selama hidup di dunia sebagai kesatuan monodualis. Sifat kodrat manusia itu terdiri dari dua aspek, sifat manusia sebagai makhluk individu dengan segala keunikannya dan sifat manusia sebagai makhluk sosial; keduanya hendaknya berjalan secara seimbang dalam merespon berbagai kepentingan. Kedudukan kodrat manusia juga mempunyai dua aspek monodualis, yaitu manusia sebagai makhluk otonom, mempunyai kebebasan dalam menentukan kehidupannya sekaligus mempunyai tanggung jawab dalam berbagai tindakan yang dipilihnya, dan manusia sebagai makhluk Tuhan yang akan kembali kepadaNya dengan mempertanggungjawabkan semua amal perbuatannya.

Dari uraian di atas, dapat disimpulkan bahwa konsep pendidikan humanis religius akan mendapatkan landasan ontologis yang kokoh jika bertitik tolak dari pandangan manusia sebagai makhluk monopluralis sebagaimana dinyatakan oleh Notonagoro.

\section{Implikasi Konsep Manusia Monopluralis dalam Pendidikan Humanis Religius}

Landasan filsafati manusia sebagai makhluk monopluralis membawa implikasi dalam pendidikan humanis religius. Bagaimana mendidik peserta didik agar menjadi orang yang humanis religius sesuai kondratnya sebagai makhluk monopluralis? Persoalan inilah yang perlu didialogkan dan dibahas bersama-sama.

Sebagai awal langkah, penulis menyampaikan beberapa pemikiran berikut: 
1. Proses pendidikan ditujukan untuk mengaktualisasikan susunan kodrat manusia.

Oleh karena manusia itu adalah makhluk beraga, maka pendidikan harus mengarah pada tujuan jasmani yang sehat sehingga dapat tumbuh kembang dan beraktivitas secara optimal. Di dalam Undang-Undang Sistem Pendidikan Nasional dinyatakan juga tentang tujuan pendidikan yang mengarah pada pencapaian tujuan manusia sehat. Dalam praksis pendidikan di Indonesia hal tersebut telah direalisasikan dengan adanya kurikulum yang memuat pendidikan jasmani atau olahraga.

Oleh karena manusia itu adalah makhluk berjiwa (cipta, rasa, karsa), maka pendidikan harus mmengarah pada upaya mengaktualisasikan potensi cipta/pikir/nalar/rasio manusia sehingga menjadi orang yang cerdas secara intelektual; memiliki ilmu pengetahuan dan menguasai teknologi yang berkembang maju sehingga mencirikan dirinya sebagai manusia yang berkompeten di bidang masing-masing. Manusia juga harus mengaktualisasikan potensi rasa sehingga menjadi orang yang peka (homo recentis), baik rasa emosionalnya maupun rasa estetisnya sehingga dalam perilakunya selalu dapat bertindak harmonis, penuh kepekaan terhadap lingkungannya dan tumbuh jiwa seni dalam dirinya untuk memperhalus budi pekerti dan kehidupan itu sendiri. Demikian pula, manusia muda perlu dididik dengan mengaktualisasikan potensi karsa (kehendak baik) sehingga menjadi orang yang bermoral baik, berkarakter atau berakhlak mulia.

2. Proses pendidikan ditujukan untuk mengaktualisasikan sifat kodrat manusia.

Hakikat sifat kodrat manusia sebagai makhluk individu dan sosial perlu dikembangkan agar menjadi aktual dalam kehidupan. Pengembangan sifat individu dalam pendidikan merupakan upaya untuk mewujudkan diri peserta didik sebagai person atau pribadi yang unik, makhluk ciptaan Tuhan yang dikaruniai dengan potensi masing-masing. Oleh karenanya, pendidikan tidak boleh menyamaratakan peserta didik. Pemahaman pendidik akan keunikan pribadi merupakan dasar untuk mewujudkan sifat kodrat individual dalam diri peserta didik.

Di sisi lain, pendidikan juga berfungsi untuk mewujudkan sifat sosial dalam diri peserta didik dengan berbagai bahan, metode, media yang dirancang sebagai 
satu kesatuan. Perwujudan manusia sebagai makhluk sosial dalam relasi dengan masyarakat sekitar, bangsa dan negara, bahkan masyarakat global perlu dirancang dalam sistem pendidikan terlebih di era informasi sekarang ini. Jangan sampai terjadi alienasi individu di dalam kehidupan masyarakat Indonesia. Hal ini sejalan dengan pilar ketiga dari prinsip-prinsip pendidikan di abad XXI oleh UNESCO: learning to live together. Masyarakat abad XXI hendaknya mengembangkan kemandirian dalam saling ketergantungan (interdependensi). Manusia tidak mungkin dapat hidup mandiri ansich tanpa saling tergantung dengan masyarakatnya, baik dalam lingkup lokal, nasional maupun global). Dikatakan oleh Jacques Delors (Ketua Komisi Internasional tentang Pendidikan untuk Abad XXI, UNESCO) bahwa barangkali jenis belajar inilah yang merupakan satu dari persoalan besar dalam pendidikan sekarang ini. Dunia sekarang sering merupakan dunia perselisihan atau pertengkaran yang memungkiri harapan sebagian penduduk dunia pada kemajuan manusia. Adalah harapan besar untuk merancang suatu bentuk pendidikan yang mampu menghindari perselisihan atau menyelesaikannya secara damai dengan mengembangkan rasa hormat terhadap orang lain, kebudayaan dan nilai-nilai spiritualnya (Delors, 1999: 67). Dalam konteks Indonesia, kekhawatiran Delors juga telah terjadi di beberapa tempat dengan adanya konflik horizontal antar etnis dan antar keyakinan yang semakin menguatkan arti penting pendidikan untuk hidup bersama secara damai, saling tergantung, dan bahagia.

3. Proses pendidikan ditujukan untuk mengaktualisasikan kedudukan kodrat manusia.

Pendidikan humanis religius dalam implementasinya hendaknya juga berfokus pada kedudukan kodrat manusia. Kodrat manusia sebagai makhluk yang otonom, bebas untuk memilih dan melakukan tindakan yang dapat dipertanggungjawabkan secara rasional, dan moral merupakan salah satu aspek penting dalam pendidikan humanis religius. Kebebasan manusia sebagai kodrat hendaknya tidak disalahpersepsikan menjadi bebas tanpa kekangan, melainkan bebas bertindak untuk memuliakan kehidupan dunia dan akhirat. Sebagai makhluk yang percaya kepada Tuhan, tidak ada kebebasan tanpa pertanggungjawaban kepadaNya. Lain halnya dengan kebebasan kaum eksistensialis atheis yang 
dimensi pertanggungjawabannya hanya untuk manusia dengan dasar pertimbangan rasional-etik sekuler semata.

Pendidikan yang humanis religius diusahakan untuk mengaktualisasikan potensi spiritualitas dalam diri manusia yang harus diwujudkan. Dasar-dasar spiritualitas-religiusitas dalam pendidikan telah menjadi bagian asasi dalam kehidupan manusia, terlebih di Indonesia yang secara tegas menyatakan sebagai bangsa yang ber-Ketuhanan Yang Maha Esa.

Pendidikan humanis religius semakin penting dikembangkan karena masyarakat dewasa ini dibingungkan tentang masalah-masalah moral, etika dalam kekacauan sosial, politik dan ekonomi serta budaya. Penting kiranya bagi para pendidik dan semua pihak yang mempunyai kepekaan dan kesadaran moral untuk merespon dan memikirkan kembali jalan keluar bagi perbaikan nilai-nilai kehidupan. Jalan yang harus ditempuh adalah kembali kepada nilai-nilai moral keagamaan. Dinyatakan oleh Mukti Ali (1998: 3-4) bahwa abad XXI adalah The First Global Revolution. Situasi dunia kontemporer sebagai sesuatu yang mengerikan sekaligus sebagai kompleksitas yang penuh harapan. Awal abad XXI adalah tahap permulaan pembentukan masyarakat dunia baru yang berbeda dengan masa lalu, yaitu suatu revolusi kehidupan pasca industri dari milenium sebelumnya. Revolusi global ini tidak dibangun dengan ideologi tunggal, melainkan dengan faktor sosial, ekonomi, teknologi, budaya dan etnik. Mukti Ali menegaskan pentingnya kembali menampilkan dimensi spiritual serta etika yang telah dikembangkan oleh agama-agama sepanjang sejarah yang selama ini dipandang tidak begitu berhasil, karena berbagai sebab. Pembangunan dimensi spiritual dan etika hendaknya lebih dipahami sebagai keniscayaan humanisme baru. Hal ini dapat diartikan sebagai seruan penting untuk mengeksplorasi kekuatan-kekuatan agama dan spiritualitas dalam membangun dunia. Mukti Ali (1998: 4) mengatakan sebagai berikut:

"Bagi orang-orang yang memiliki wawasan mendalam, pentingnya transformasi dunia bagian luar tidak mungkin terjadi tanpa transformasi bagian dalam yang sebenarnya. Bagaimana kita dapat menciptakan keseluruhan (wholeness) dan harmonitas dalam dunia yang hancur? Untuk mengubah petunjuk pikiran dan tindakan manusia, kita dapat menemukannya dalam warisan agama-agama dunia, melalui cara 
perenungan sebagaimana mestinya. Kita sering melupakan bahwa jika penduduk dunia kurang lebih 5.000 juta jiwa, hanya 1000 juta yang menganut paham sekuler, 4000 juta jiwa lainnya mempunyai pandangan agama-agama dunia...".

Selanjutnya, Mukti Ali (1998: 14) mengemukakan alasan pentingnya peningkatan dimensi transendental dari eksistensi manusia. Selama ini model berpikir atau paradigma sekuler yang mendominasi dalam membentuk pikiran manusia, bentuk-bentuk personalitas dan menciptakan landasan dalam memandang realitas. Demikian pula dalam sistem pendidikan yang dikembangkan umumnya merujuk pada paradigma tersebut. Paradigma sekuler sebagai hasil dari sejarah pencerahan masyarakat Eropa adalah sangat merusak; sama sekali tidak menciptakan kemungkinan kemajuan pada diri seseorang, kecuali dalam kaitannya dengan ilmu pengetahuan, teknologi, produksi dan manipulasi lingkungan. Sebaliknya, pendidikan agama yang selama ini dilaksanakan begitu jauh menekankan pendidikan spiritual dan kurang memberi perhatian pada ilmu pengetahuan, teknologi dan cabang-cabang pengetahuan lainnya. Maka, perlu sintesis pengetahuan yang mencakup kesemestaan pandangan (holistik). Agama, ilmu pengetahuan dan teknologi saling bertemu dan menyapa dalam ruang-ruang belajar peserta didik dalam kesatuan yang harmonis tanpa kotak dan sekat.

Jadi, sebagai aktualisasi hakikat kodrat manusia, pendidikan diharapkan akan mampu mewujudkan kodrat kemanusiaan yang utuh. Segala potensi manusia dapat diaktualisasikan di dalam pendidikan dan setelahnya. Hal tersebut juga sejalan dengan pernyataan Thomas Armstrong (2006) bahwa tujuan pendidikan adalah untuk mendukung, mendorong, dan memfasilitasi perkembangan peserta didik sebagai manusia yang utuh (a whole human being). Dengan demikian dapat ditarik suatu benang merah bahwa pendidikan humanis religius dapat dikembangkan dengan berlandaskan pandangan mengenai manusia sebagai makhluk monopluralis sebagaimana dikonsepkan oleh Notonagoro. 


\section{Adakah Praktik Pendidikan Humanis Religius di Sekolah?}

Secara operasional, seperti apakah proses pendidikan humanis religius itu? Berkaitan dengan hal tersebut, perlu dilihat dari berbagai unsur pendidikan, terutama yang terkait dengan interaksi timbal balik antara pendidik dan peserta didik.

Interaksi pendidik dan peserta didik dibayangkan sebagai interaksi dialogis yang saling menghargai harkat dan martabat masing-masing. Pendidik sebagai orang yang berada di depan memberi contoh teladan yang baik dalam sikap dan perilakunya yang mencerminkan sebagai orang yang humanis religius. Pendidik yang humanis memberi kesempatan untuk peserta didik berkembang, penuh dengan sikap welas asih dan memberi kesempatan peserta didik memperbaiki kesalahan yang telah dibuatnya.

Pendidikan humanis religius mengutamakan pembelajaran aktif dan menggunakan metode dialog dalam suasana pembelajaran yang dirancang dengan menghadirkan Tuhan, dalam suasana nyaman, aman, ramah, santun, bahagia. Hal tersebut sejalan dengan pernyataan Ki Hadjar Dewantara (1977): "Pendidikan adalah tuntunan di dalam hidup tumbuhnya anak-anak, yaitu menuntun segala kekuatan kodrat yang ada pada anak-anak itu agar sebagai manusia dan sebagai anggota masyarakat dapat mencapai keselamatan dan kebahagiaan yang setinggi-tingginya."

Secara singkat dapat dinyatakan bahwa praktik pendidikan humanis religius berlangsung dalan situasi pembelajaran yang saling menghargai, saling memberi nilai tambah bagi pengayaan kualitas kehidupan baik sebagai individu, anggota masyarakat, maupun makhluk berTuhan.

Bagaimana praktik pendidikan di sekolah-sekolah kita? Sudahkah para pendidik di sekolah-sekolah Indonesia mencerminkan pendidik yang humanisreligius? Apakah para pendidik memahami tujuan pendidikan nasional yang bersifat humanis religius tersebut? Pertanyaan-pertanyaan tersebut dapat dijawab bila telah ada kajian atau penelitian yang seksama. Hanya saja, sebagai gambaran umum dapat disampaikan beberapa hal yang merupakan simpulan dari berbagai hasil penelitian pendidikan di Indonesia akhir-akhir ini yang dipandang dalam perspektif pendidikan humanis religius.

Di sebuah sekolah dasar (sebut saja SD Cahaya) terdapat pendidikan yang bersifat humanis religius. Berikut ini adalah gambarannya: 
Pagi-pagi sekali anak-anak datang ke sekolah. Pukul 6.30 kepala sekolah dan guru sudah menunggu di depan pintu gerbang menyambut anak-anak yang datang. Diucapkannya salam dengan lembah lembut pada anak-anak didiknya tersebut sambil diusap atau ditepuk punggungnya tanda keakraban dan kedekatan. Anak-anak membalas salam tersebut sambil bersalaman dengan guru dan kepala sekolah. Setelah itu mereka menuju ruang kelas masing-masing. Di dalam kelas, anak-anak menunggu bel berbunyi tanda mulai masuk pelajaran. Para guru masuk ke kelas masing-masing sesuai dengan jadwal yang telah ditetapkan. Guru membuka kelas hari itu dengan cerita-cerita ringan, bertanya kabar pada masing-masing anak. Guru dan murid duduk di lantai membentuk posisi lingkaran sehingga masing-masing merasa dekat dan akrab. Guru dan murid tidak terlalu bersekat, semuanya berperan membentuk lingkaran. Guru mempersilahkan anak-anak yang akan mengemukakan pendapatnya atau cerita-cerita sehari-hari yang ringan-ringan seperti apa yang dikerjakan sehari sebelumnya, mimpi semalam, pengalaman liburan, dsb. Setelah itu kegiatan keagamaan berupa membaca kitab suci dan menghafal ayat-ayat Ilahi. Kemudian kegiatan pelajaran umum seperti matematika, bahasa Indonesia, dan lainlain dengan menggunakan pendekatan learning by doing (belajar dengan melakukan) dan student centered learning sehingga pembelajaran lebih menghargai peserta didik sebagai person yang menjadi subjek dalam belajar. Pembelajaran juga menjadi menyenangkan dan menarik bagi peserta didik. Pelajaran dirancang tidak hanya dilaksanakan di dalam kelas, melainkan juga dengan kegiatan di luar kelas, observasi ke kebun sekolah, ke sungai, ke sawah dan juga ke rumah-rumah penduduk, kegiatan outbond dan kemah semuanya dilakukan sesuai dengan tujuan pembelajaran. Ketika jadwal ulangan tiba, para siswa tidak tampak resah atau gelisah. Mereka sendiri yang mempersiapkan tempat duduk dengan memindahkan meja sesuai aturan yang telah ditetapkan. Bila ada siswa yang belum mencapai kriteria kemajuan belajar, siswa diberi kesempatan untuk remidi sampai berhasil,tanpa ada pelabelan anak bodoh oleh guru.

Jika ada anak-anak yang nakal, guru mengumpulkan semua siswa untuk membahas bersama permasalahan atau kenakalan yang terjadi. Masing-masing siswa diberi hak untuk menyatakan pendapatnya terkait ketidaknyamanan yang dirasakan akibat ulah temannya yang telah berbuat nakal. Guru kemudian memberikan 
kesimpulan bahwa akibat kenakalan yang telah dibuat oleh siswa tersebut membuat teman-temannya menjadi tidak nyaman, suasana kelas menjadi tidak harmonis dan tidak kompak. Setelah itu, guru memberi kesempatan pada siswa yang melanggar atau berbuat onar untuk menanggapi pendapat dan perasaan teman-temannya dan juga menyatakan penyesalannya. Pada tahap ini siswa yang nakal tersebut biasanya meminta maaf pada teman-temannya dan berjanji tidak akan berbuat keonaran lagi. Demikianlah dalam praktik pendidikan terjadi dialog yang dilandasi oleh keterbukaan, kejujuran dan saling menghormati baik antar siswa maupun siswa dan guru sehingga terjalin kesepahaman dan empati untuk memperkuat "sense of community" di kelas dan sekolah.

Di samping praktik pendidikan yang mencerminkan konsep pendidikan humanis religus, terdapat pula praktik pendidikan yang tidak humanis-religius. Penelitian Ariefa Efianingrum $(2009,2010)$ tentang pendidikan anti kekerasan di sekolah diperoleh fenomena sebagai berikut:

Di sebuah SD di Yogyakarta sebut saja SD Tugu ada guru yang sering melakukan kekerasan. Ketika upacara ada siswa yang berbicara atau mengobrol dengan temannya; tidak memperhatikan amanat inspektur upacara, seorang guru tiba-tiba menghampiri siswa yang mengobrol tersebut dan menendangnya sehingga jatuh tersungkur. Alasannya, siswa patut dihukum untuk mengajarkan kedisiplinan karena telah berbuat kesalahan. Pertanyaannya adalah apakah hukuman itu sepadan dengan kesalahan yang telah dilakukan atau malah justru berlebihan atau terlalu berat? Terkadang guru tidak berpikir panjang bahwa hukuman yang diberikan sebenarnya telah merendahkan harkat dan martabat anak didiknya dihadapan temantemannya dan guru-gurunya. Tidakkah lebih baik bila anak tersebut setelah upacara dibawa ke ruang guru untuk kemudian diberi nasehat dan pengertian akan pentingnya kedisiplinan dan pentingnya upacara untuk menanamkan rasa nasionalisme. Atau dapat pula diberi tugas untuk membuat karangan tentang pentingnya upacara bendera bagi siswa.

Di sebuah sekolah dasar negeri di Yogyakarta ada sekelompok peserta didik yang telah mempunyai gang bermain berdasarkan merek handphone (HP) yang dimiliki. Khusus siswa yang memiliki merek HP mahal berkumpul dengan sesamanya, sedangkan siswa yang tidak memiliki HP atau memiliki tetapi HP biasa 
saja; mereka ini tidak boleh masuk dalam kelompok eksklusif tersebut. Mereka hanya bermain dengan sesama pemilik HP mahal. Hal tersebut telah diketahui guru tetapi guru membiarkan saja seolah bukan suatu masalah besar yang harus diselesaikan. Jelaslah bahwa guru kurang peka terhadap persoalan yang dihadapi di kelas dengan peserta didiknya. Guru tidak membimbing peserta didiknya untuk membentuk solidaritas dan saling mengasihi, tetapi justru membiarkan potensi konflik tumbuh dalam diri peserta didik. Sementara Ki Hadjar Dewantara mengatakan bahwa pendidikan itu hendaknya dilaksanakan dengan prinsip asah, asih, asuh. Dari fenomena ini guru seolah melepas tanggung jawab mendidik dan mereduksi tugasnya hanya sampai pada pengajaran saja. Masalah pembentukan karakter peserta didiknya seolah bukan tugasnya, tetapi tugas orang tua masingmasing.

Demikian gambaran singkat fenomena pendidikan di SD yang ada di Yogyakarta. Dari fenomena tersebut dapat diketahui bahwa walaupun pendidikan nasional kita telah menetapkan tujuan pendidikan yang bersifat humanis religius, tetapi dalam upaya mencapai tujuan tersebut ada sekolah yang telah melaksanakan praktik pendidikan sesuai dengan tujuan pendidikan nasional, dan ada pula yang justru malah melenceng dari tujuan yang telah ditetapkan. Berbagai permasalahan tersebut perlu diatasi dengan berbagai solusi yang sistemik. Maka, penting bagi para pengambil kebijakan, dalam hal ini Mendikbud dan jajarannya untuk menengok kembali praktik pendidikan yang telah dilaksanakan dan mengevaluasi apakah sejalan dan mengarah pada tercapainya tujuan pendidikan nasional yang bersifat humanis religius atau justru mencederai tujuan tersebut. Perlu ada sosialisasi dan internalisasi terus-menerus kepada para guru dan praktisi pendidikan agar dapat menjalankan tugas mendidiknya sesuai dengan prinsip pendidikan yang humanisreligius. Semoga semakin banyak guru-guru dan pendidik yang humanis-religius di Indonesia. 


\section{DAFTAR PUSTAKA}

Ariefa Efianingrum, dkk. 2009/2010. Pengembangan Model Pendidikan Respek untuk Mencegah Kekerasan di Sekolah. Laporan Penelitian Strategis Nasional, Lembaga Penelitian UNY.

Armstrong, Thomas. 2006. The Best School: How human development research should inform educational practice. Virginia: Association for Supervision and Curriculum Development.

Budi Hardiman, F. 2007. Filsafat Modern: Dari Machiavelli sampai Nietzsche. Jakarta: Gramedia Pustaka Utama.

Delors, Jaqcues (ed.). 1999. Belajar: Harta Karun Di Dalamnya. Jakarta: Depdikbud-UNESCO Paris.

Driyarkara. 1980. Driyarkara tentang Pendidikan. Yogyakarta: Kanisius.

Mukti Ali. (1998). “Agama, Moralitas dan Perkembangan Kontemporer”. Dalam Mukti Ali, dkk. Agama dalam Pergumulan Masyarakat Kontemporer. Yogyakarta: Tiara Wacana.

Notonagoro. 1987. Pancasila secara Ilmiah Populer. Jakarta: Pantjuran Tudjuh.

Tim Penyusun. 1977. Karya Ki Hadjar Dewantara - Bagian Pertama: Pendidikan. Yogyakarta: Majelis Luhur Taman Siswa.

Sodiq A. Kuntoro. 2013. Formulasi Model Pendidikan Humanis Religius. Makalah Workshop Pengembangan Pendidikan Humanis Religius FIP UNY 16 November 2013 di Yogyakarta. 